\title{
Psychological Contract and Job Satisfaction among HR Professionals in Start-up Service Sector
}

\author{
Lijo. K. J ${ }^{1 *}$, Wanlamkupar Savio Lyngdoh ${ }^{2}$
}

\section{ABSTRACT}

Psychological contract pinpoints the underlying processes regarding expectation within the employee and employer relationship to ensure a healthy and progressive relationship of both parties. Human resource professionals in Start-up have a bigger role than those working in large organization. The researcher aims to find out whether there is a relationship between Psychological contract and Job Satisfaction among HR professionals. The objective of the study to find the relationship between psychological contract and job satisfaction among HR professionals in start-up organization. The tools used for the study are the Job Satisfaction scale by (Singh \& Sharma, 2004) and Psychological Contract Inventory (Rousseau, 1989). The sample of the study consists of $40 \mathrm{HR}$ professionals. Pearson product moment correlation and step-wise multiple regression is used for analyzing the data. The findings show that the dimensions of psychological contract inventory i.e. employee obligation, employer obligation and psychological contract fulfillment have a significant correlation with job satisfaction of HR professionals in Start-up service sectors.

Keywords: Human Resource Professionals, Psychological Contract, Job Satisfaction

Psychological contract is individual's belief regarding reciprocal obligations in a dual relationship in a dual relationship such as employment (Sebastian, 2015). Psychological contract refers to the expectations which employee and employer have from each other and what they owe to each other (Agarwal, 2014). Psychological contract deals with implicit reciprocal promises and obligations, the employer and the employee to manage differences pertaining to personality characteristics, demographic factors, and environmental, organizational characteristics and to correct the deviations for enhancing organizational performance and wellbeing of employees. Rousseau classifies psychological contract into two i.e. transactional contract and relational contract to define the kind of employer - employer relationship. Relational contracts concern a relationship built on trust, implicit emotional attachment and long

\footnotetext{
${ }_{1}^{1}$ Assistant Professor, Department of Psychology, Christ University, Begaluru, Karnataka, India

${ }^{2}$ M.Sc Student, Department of Psychology, Christ University, Begaluru, Karnataka, India *Responding Author

(C) 2016 I K Lijo, W Lyngdoh; licensee IJIP. This is an Open Access Research distributed under the terms of the Creative Commons Attribution License (http://creativecommons.org/licenses/by/2.0), which permits unrestricted use, distribution, and reproduction in any Medium, provided the original work is properly cited.
} 
term employment. Transactional contract is short term, monetary based, limited emotional attachment, direct exchange and identifiable competencies (Rousseau, 2000).

A study conducted among personal management staff, and employee supervisors in Garment sector in Indian NTCs (National Textile Corporation) has found that experience and long tenure related with employee job involvement. The study also found that job involvement and quality of work life are more among long term employees and permanent employees than contract employees (Lijo \& Amurtha, 2013). This shows that tenure and job permanence has an impact on employees' psychological contract with organization, organizational commitment, job involvement and job satisfaction (Chambel \& Castanheira, 2007). Study conducted by Coyle Shapiro and Kessler (2002) has noticed similar conclusions. They found that compared to temporary employees, the felt obligation and positive psychological contract are more among permanent employees. Millward and Hopkins (1998) reported that relational psychological contract is high among permanent employees than temporary employees who show more transactional Psychological contract. Similar finding has also been noticed by Saunders and Thornhill (2006); and Burgess and Connell (2006).

A study conducted in Taiwanese high-tech context found that, in the perception of both managers and employees, the key predicators of the HR effectiveness are their field expertise and change management skills and strategies (Han, Chou, Chao \& Wright, 2006). A survey conducted among 342 HR professionals has noticed that relationship with immediate supervisor, opportunities to use your, skills and abilities, communication between employees and senior management, autonomy and independence, organization's financial stability, work itself are the great contributors of job satisfaction (Employee Job Satisfaction, 2014). The established relationship between the above mentioned factors and HR professionals' organizational effectiveness and job satisfaction would be the result of strong built psychological contract between the organization and HR employees in long run.

Human resource (HR) professionals are the representatives of management in front of employees and representatives of employees in front of management. On the reflection of both parties (Management and employees) they design policies, strategies and practices related to recruitment and selection; training and development; and appraisal and feedback. Human resource professionals manage the employer-employee relationship and align an organization culture with its people. The mid role played HR professionals is both an opportunity and challenge. Since they make use of the challenges has impact on the optimal functioning of themselves and whole organization. Strategic human resources management (SHRM) practices are a well functioning HR model which has significant positive impact not only on organizational performance and employees well-being but also on the performance, organizational commitment and job satisfaction among HR professionals (Green, Wu, Whitten \& Medlin, 2011). 
In the present study the researchers tries to study the relationship between psychological contract and job satisfaction among fresher HR professional in startup organizations. This study would help to understand; what is the impact of psychological contract on Job satisfaction Fresher HR professionals in short run? It is another question that, To which extend Fresher HR professional and Start-up organizations can come to a psychological contract in short run? A study among Fresher HR professional seems to be relevant in the context of two research observations. 1) Employability of HR professional graduates is less than 10\% (aspiringminds, 2014). 2,) The percent of HR professionals with above 20 years of experience is 2; between 10-19 years of experience is 24; between 5-9 years of experience is 47; between 1-4 years of experience 26; and less than 1 year of experience is 6 (PayScale, 2015).

From the view point of the Process theory of job satisfaction (Worrell, 2004), psychological contract could be established as a result of how well the job meet one's expectation and values are being appreciated by employee or employer; and job satisfaction is the best outcome of it. With answers for the above questions, organizations would be able to acknowledge different kind of contracts and needed employee-organization facilitation for positive psychological contract.

\section{METHODOLOGY}

\section{Objective}

To find out the relationship between psychological contract and job satisfaction among HR professionals in start-up organizations.

\section{Hypothesis}

H0.1: There is no relationship between psychological contract and job satisfaction among HR professionals in Start-up organization.

\section{Sample}

The populations that will be used for the study comprise HR Professionals, working in start-up organizations. The sample consists of 40 fresher HR professionals belonging to four start-up IT organizations from Bengaluru, Karnatka, India. The experience of the participants was ranging from 1 year to 3 years. The age of participants was ranging from 20 years of age till 30 years. The ethical guidelines related to the rights and confidentiality of participants had followed

\section{Tools}

Job satisfaction scale (Singh \& Sharma, 2004): Job Satisfaction is as a pleasurable or positive emotional state resulting from the appraisal of one's job or job experiences (Locke (1976). It contains 30 items and rated on a five point response options. The level of job satisfaction is measured on two types- job intrinsic and job extrinsic. The test retest reliability works out to be 0.98 and validity of 0.74 . 
Psychological contract inventory (Rousseau, 1989): A psychological contract is an individual's belief in mutual obligations between that person and another party, such as an employer (Rousseau, 1989). The inventory measured four elements of psychological contract namely, employee obligation, employer obligation, psychological contract transitions and psychological contract fulfillment. Employee Obligations to words the employer and organization and Employer obligation to wards employee measured on seven sub-sections namely, Short-term, Loyalty, Narrow, Dynamic Performance, Internal Development, External Development, and Stability. The psychological contract transition had three sub-sections namely Uncertainty, Mistrust, and Erosion. The psychological contract fulfillment two sub-sections namely employee fulfillment and employer fulfillment. Except for Psychological Contract fulfillment's sub sections, all the subsection of the inventory had four items with a five point response options. The total high score for each element of psychological contract inventory indicate high level of attribute for the employee.

\section{Statistical analysis}

To test the hypothesis, the study used Pearson product moment correlation and Step-wise multiple regression Analysis.

\section{RESULTS AND DISCUSSION}

The objective of the research was to study the relationship between Psychological Contract and Job Satisfaction among Fresher HR professionals in IT industry.

Table 1 Summary of demographic characteristics of HR professionals of the study

\begin{tabular}{|l|r|r|}
\hline Variable & Frequency & Percent \\
\hline Age & 15 & \\
\hline $20-25$ & 25 & \\
\hline $26-30$ & & \\
\hline Gender & 15 & 37.5 \\
\hline Female & 25 & 62.5 \\
\hline Male & & \\
\hline Education Level & 6 & 15.0 \\
\hline Bachelor Degree & & 22 \\
\hline Post Graduation & & 55.0 \\
\hline MBA & 40 & 30.0 \\
\hline Total & & 100 \\
\hline
\end{tabular}

The Table 1 indicates the demographic details of the sample. The participant's age ranged from 20 years to 30 years with an average 26.5 years. The sample had maximum number of participants who fell in the range between 26 to 30 years (62.5\% of the total sample). The remaining participant's age ranged between 20 to 25 years (37.5\% of the total sample). The 
sample consisted of 15 females (37.5\% of the sample) and 25 males (62.5\% of the total sample). The education level was also obtained and 22 people have a Post Graduation degree (55\% of the sample); 6 people have a Bachelor degree (15\% of the sample) and 12 people have a MBA degree (30\% of the sample).

Table 2: Mean, SD and Result of Shapiro-Wilk Test of Normality of scores on psychological contract (PC) and job satisfaction

\begin{tabular}{|l|c|c|c|}
\hline Variables & Mean & SD & $W$ \\
\hline Job Satisfaction & 69.80 & 11.35 & $.11^{*}$ \\
\hline Employee Obligation & 88.55 & 11.22 & $.09^{*}$ \\
\hline Employer Obligation & 88.07 & 10.63 & $.10^{*}$ \\
\hline PC Transitions & 28.03 & 8.48 & $.11^{*}$ \\
\hline PC Fulfillment & 14.10 & 3.23 & $.09^{*}$ \\
\hline
\end{tabular}

$*=p>.05$

The Shapiro-Wilk Test was also performed and a value above 0.05 indicating the all the variables are normally distributed.

H0: There is no relationship between psychological contract and job satisfaction among HR professionals in Start-up organization.

Table 3: Relationship between psychological contract (PC) and job satisfaction among HR professionals

\begin{tabular}{|l|l|l|l|l|}
\hline Variable & $\begin{array}{l}\text { Employee } \\
\text { Obligation }\end{array}$ & $\begin{array}{l}\text { Employer } \\
\text { Obligation }\end{array}$ & PC Transitions & PC Fulfillment \\
\hline Job Satisfaction & $.36^{*}$ & $.63^{* *}$ & $-.68^{* *}$ & $.53^{* *}$ \\
\hline
\end{tabular}

$*=\mathrm{p}<0.05, * *=p<0.01$

The first dimension of psychological contract indicate that there was a positive significant correlation between employee obligation and job satisfaction, as $r=.36, p=0.05$. The second dimension of psychological contract indicate that there was a positive significant correlation between employer obligation and job satisfaction, as $r=.63, p=0.01$. The third dimension of psychological contract indicate that there was a negative significant correlation between psychological contract transitions and job satisfaction, as $r=-.68, p=0.01$. The fourth 
dimension of psychological contract indicate that there was a positive significant correlation between psychological contract fulfillment and job satisfaction, as $r=.53, p=0.01$.

Psychological contract is the degree of trust-belief among employee and employer on the basis of implicit and explicit commitments. Studies have examined the causes and outcomes of psychological contract and its impact on organizational and employee wellness (Sturges, Conway, Guest \& \& Liefooghe, 2005; Rousseau, 2000). The present study examined the relationship between psychological contract and job satisfaction of HR professionals in Start-up organization. On conducting Pearson correlation amongst dimension of psychological contract with job satisfaction, from Table 3, it was found that among Fresh HR professionals four elements of psychological contract, namely employee obligation, employer obligation, psychological contract transition and of psychological contract fulfillment, found related to job satisfaction. The result of the correlation test was according to the normal expectation. The elements of psychological contract such as employee obligation, employer obligation and psychological contract fulfillment showed a significant positive correlation with job satisfaction. These three elements are positive elements which will lead to employee commitment and work motivation among Fresher HR professionals. There are studies which has already established positive relationships between positive aspects of psychological contract and job commitment (Lemire \& Rouillard, 2005; Sturges et al., 2005). Significant negative correlation between psychological contract transition and job satisfaction among Fresher HR professionals was also according to the expectation of review. This shows that any perceived negative change in the expected outcome of psychological contract may be considered by Fresher HR employees as a violation in psychological contract will have negative impact on employees (Kraft, 2008).

Table 4: Result of Step-wise multiple regression analysis finding the predictive relationship between psychological contract (PC) and job satisfaction.

\begin{tabular}{|l|c|c|c|c|c|c|}
\hline Variables & & Model 1 & & & Model 2 & \\
\hline & $B$ & $S E B$ & $\beta$ & $B$ & $S E B$ & $\beta$ \\
\hline PC Transitions & -.91 & .15 & -.68 & -.63 & .20 & -.47 \\
\hline Employer Obligation & & & & .34 & .16 & .32 \\
\hline $\mathrm{R}^{2}$ & & .46 & & & .52 & \\
\hline$F$ & & $32.92 * *$ & & & $20.29 * *$ & \\
\hline$* *=\mathrm{p}<.01$
\end{tabular}

$* *=\mathrm{p}<.01$

Since the elements of Psychological contract had significantly correlated with HR professionals", job satisfaction, they have included in Step-wise multiple regression analysis. In model 1, psychological contract transition predicts job satisfaction with a variance of $46 \%, B=-.91, F(1$, $39)=32.92, p=.001$. In model 2 , employer obligation and psychological contract transition predicts job satisfaction with a variance of $52 \%, B=-.63, F(1,39)=20.29, p=.001$. 
In the final model of step-wise regression, two variables turned as important predictors of job satisfaction among HR professional i.e. psychological contract transition and Employer obligation. This shows that employers commitment and its successful progression are supportive and encouraging conditions for fresher HR employees and any sign of violation or change is negatively affecting the commitment and job satisfaction. Human Resource professionals who are working in Start-up sector have a bigger role than those working in large organization. Human resource professionals in Start-up have a bigger role than those working in large organization. In smaller organization like Start-ups there is an opportunity to get involved in all aspects of the business and also decision making. Human resource professionals thus have a lot of things to do unlike in bigger organization where the role is more focused on a particular area. The role changes as the needs of the business do. In a Start-up the need for basic HR operations is very important i.e. recruiting the right people and making sure everything is going on effectively. They need constant support and encouragement from management on a large scale. So a positive psychological cal contract is highly essential for a fresher HR employee to be committed and to derive satisfaction from the commitment. Psychological contract pinpoints the underlying processes regarding expectation within the employee and employer relationship to ensure a healthy and progressive relationship of both parties.

\section{CONCLUSION}

In India long term career path of HR professional are very narrow. Graduates of HR have a hard time to stabilize in their profession especially when they are in Start-up organizations. Perceived organizational support for HR functions and career goals are key factors of HR employee job satisfaction. In this context, the study the relationship between Psychological contract and job satisfaction exclusively among Fresher HR Professionals in Start-up IT industries. The findings show the importance of perceived psychological contract for job satisfaction of Fresher HR professionals. But the scope of generalization of the study is limited because of limited sample size. So findings cannot be generalized to experienced HR professional in established/ bigger organizations.

\section{REFERENCES}

Agarwal, P. (2011, October). Relationship between psychological contract \& organizational commitment in Indian IT industry. Indian Journal of Industrial Relations, 47(2), 290-305.

Aspiringminds (2014-15). National Employability Report. MBA Graduates 2012. Retrieved from http://www.aspiringminds.com/research-articles/national-employability-report-mbagraduates-2012PayScale (2015).

Burgess, J. and Connell, J. (2006). Temporary work and human resources management: issues, challenges and responses", Personnel Review, 35 (2), 129 - 140.

Chambel, M.J. \& Castanheira, F. (2006). Differenttemporary work status, different behaviors in organization. Journal of Business and Psychology, 20, 351-367. 
Coyle-Shapiro, J.A-M., \& Kessler, I. (2002). Reciprocity through the lens of the psychological contract: Employee and Employer perspectives. European Journal of Work and Organizational Psychology, 11: 1-18.

Employee Job Satisfaction (2014). Trends in Compensation and Benefits. Employee Job Satisfaction and Engagement. Retrieved from https://www.shrm.org/Research/SurveyFindings/Documents/140028\%20JobSatEngage_S pecial\%20Sections.pdf

Green, K. W., Wu, C., Whitten, D., \& Medlin, B. (2011). The impact of strategic human resource management on firm performance and HR professionals' work attitude and work performance. The International Journal of Human Resource Management, 17(4), 559-579.

Han, J., Chou, P., Chao, M., \& Wright, P. M. (2006). The HR competencies-HR effectiveness link: A study in Taiwanese high-tech companies. Human Resource Management, 45(3), 391-406.

Karft, J.M. (2008). Psychological contracts and organizational commitment profiles: Effects of contract fulfillment and violation on employee outcomes. Unpublished Masters dissertation University of Windsor. Retrieved from http://web2.uwindsor.ca/ckwantes/lab/Psycholgical\%20contracts\%20and\%20organizatio nal\%20commitment\%20profiles.pdf

Lemire, L., \& Rouillard, C. (2005). An empirical exploration of psychological contract violation and individual behaviour: The case of Canadian federal civil servants in Quebec. Journal of Managerial Psychology, 20(2), 150-163.

Lijo. K.J., \& Amrutha, P. (2013). Job involvement of Textile employees with regards to quality of life. International Journal for Research and Development, 1(4), 27-30.

Locke, E.A. (1976). The nature and causes of job satisfaction. In M.D. Dunnette (Ed,), Handbook of Industrial and orgnizational Psychology (pp.1297-1343). Chicago: Rand McNally.

Millward, L.J., \& Hopkins, L.J. (1998). Psychological contracts, organizational and job commitment. Journal of Applied Psychology, 28(16), 1530-1556.

PayScale (2015). Human Resources (HR) Manager Salary (India). Retrieved from http://www.payscale.com/research/IN/Job=Human_Resources_\%28HR\%29_Manager/Salary

Rousseau, D. M. (2000). Psychological Contract Inventory, Revised Version: Technical Report.

Sebastian, M. S., \& A.P, D. G. (2015). Psychological Contract in the Indian Aviation. Indian Journal Of Research, 8, 78-94.

Sturges, J., Conway, N., Guest, D., \& Liefooghe, A. (2005). Managing the career deal: The psychological contract as a framework for understanding career management, organizational commitment and work behavior. Journal of Organizational Behavior, 26, 821-838.

Worrell, T. G. (2004). School Psychologist Job Satisfaction: Ten Years Later. 6, 96-107. 